\title{
FINANCIAL INCLUSION IN INDIA-AN OVERVIEW
}

\section{R. KEDARANATHA SWAMY}

Assistant Professor of Economics, Government First Grade College-Kadur, Chikkamagluru (Dist)-577548, Karnataka

ABSTRACT
Financial inclusion is having a significance impact towards greater financial inclusion. Iimprove the financial inclusion
the Indian Government has announced Pradhan Mantri Jan DhanYojana nationwide through access to faster and easy
banking facilities. The rationale of this article is to investigate the impact of demonetisation on financial inclusion.And it
attention on the many initiatives taken by the government to achieve financial inclusion. After careful reviewing the
literature and analysing that, it is found that for financial inclusion demonetization was making little challenges but after
introducing faster financial banking system, the inclusive growth is taking place but still the rural and uneducated group
of people facing many challenges for adopting this new initiatives of the government in the area of financial inclusion
and new facing in thebanking sector.
KEYWORDS: Financial Inclusion, Demonetization, PMJDY, Government Initiatives

Received: Jul 04, 2021; Accepted: Jul 24, 2021; Published: Aug 14, 2021; Paper Id.: IJECRDEC20215

\section{INTRODUCTION}

For the comprehensive growth of India the role of financial inclusion is an important feature. It assists to the vulnerable population's overall economic development. Effective financial inclusion is required in India to improve the lives of the poor and vulnerable by providing them with modern financial goods and services.

Financial inclusion can be defined as the process of providing vulnerable groups, such as weaker portions and low-income groups, with inexpensive access to financial services as well as timely and enough financing when needed. The basic purpose of financial inclusion is to provide low-cost access to a variety of financial services, such as savings, credit, insurance, remittance, and other bankable households and businesses. When people from the poorer sections of society have access to credit and savings accounts, their financial security improves. A financial inclusion upgrades the quality of living and eliminates the poverty and allows the people to contribute more to the economy.

Demonetization, which was declared by Prime Minister Sri Narendra Modi on November 8, 2016, to prohibit all outdated higher denominations, paved the way for leveraging money to grow the economy for all the illegal activities of funding terrorist's activities, to curb black money and corruption by nullifying nearly $86 \%$ of circulation of notes.

\section{OBJECTIVES}

- To know the significance of financial inclusion.

- To review the effect of Demonetization on India's financial inclusion.

- To know the initiative taken by the Government to achieve financial inclusion. 


\section{LITERATURE OF REVIEW}

Dr. Samuel Schueth and Alex Moler (2017) discuss how demonetisation impacts customers and retailers, as well as their feelings about it. Account registration and active and advanced use of registered accounts increased as a result of demonetization. It had a considerable positive impact on improving financial inclusion when compared to previous initiatives.(Moler, 2017).

Financial inclusion, according to Josiah Aduda and Elizabeth Kalunda (2012), is a precondition for economic growth.International and national organisations have mirrored this sentiment. Financial isolation has been linked to social exclusion intheir studies. This demonstrates the importance of financial inclusion in achieving inclusive development(Kalunda, 2012).

In order to achieve financial inclusion, financial instruments for the poor must be developed that better serve the purpose of socioeconomic development. For future growth of institutions, government policies must be incorporated, and innovation is required to stimulate the financial sector.

\section{FINANCIAL INCLUSION AND ITS IMPORTANCE}

Financial inclusion broadens the financial system's resource base by encouraging a savings culture among a substantial segment of the rural population, It is also significant in the growth of an economy.

- Financial inclusion puts the unbanked people into contact with the official banking system.

- By allowing easy access to formal credit, financial inclusion decreases the abuse of vulnerable populations by money lenders.

- Financial inclusion provides a foundation for instilling the habit of saving.

- Financial inclusion gives the poorer members of society access to formal credit.

- Access to financial services makes it easier for the poorest members of society to escape poverty and minimises social inequality.

- Individuals, families, and communities may all contribute to economic growth through financial inclusion.

- Financial inclusion empowers men, women, and by giving them access to a bank account, a savings account, and a payment mechanism.

- Financial inclusion enables the people to manage their earnings and encourage to save their money.

- Financial inclusion safeguards an individual's financial wealth and other assets in times of crisis.

- Investment within the community provides employment opportunities as a result, one's status, money, and outlook on life improve.

- Financial inclusion equips people with the knowledge and skills they need to make sound financial decisions.

- Participating in the financial system provides a variety of individual benefits, including the ability to pay for a child's education, enabling for the emergence of a new generation of educated and aware people 
- Fulfil the gaps and leaks in public subsidy and welfare programmes which are meant for the vulnerable groups.

\section{Demonetization's Impact on India's Financial Inclusion}

Demonetization started when Prime Minister announced on $8^{\text {th }}$, November 2016, the government would no longer recognize existing 500 and 1,000 rupees notes as valid forms of legal tender. Despite the fact that the decision to demonetise created enormous social and economic disruption, it led in a number of financial system changes that helped to increased financial inclusion. The most major modifications are shown below:

Significant growth in bank deposits - As of December 30, up to 97 percent of the demonetized bank notes had been deposited in banks, which had received a total of $\$ 14.97$ trillion out of the total of $\$ 15.4$ trillion demonetized.During the period, deposits in PMJDY accounts alone increased to almost Rs. 64000 crore, with 18 million additional Jan Dhan accounts established.

Marginal Cost of Funds based Lending Rates (MCLR) -Since the larger circulation of money, it enhances the liquidity of the banks. This results in lower lending rates and lower EMI's. Deposits with banks increased by Rs.3.5 lakh crore between November 2016 and March 2017, boosting total profits.

Greater financial inclusion- Under the PMJDY initiative, 50 million new accounts have been opened after demonetisation by October 2017 which leads conversion of unbanked into banked population so that they can avail easy credit facilities.

Digital finance - The country is heading toward a cashless economy, as seen by the increased use of digital finance. There has been a rise in the number of digital mode systems. And they are -

- $\quad$ EFT/NEFT - National Electronic Fund Transfer (NEFT) is an Indian electronic money transfer system that allows you to send money from one bank or bank branch to another.According to RBI data, NEFT volume and value climbed by $20 \%$ and 24\% respectively from November 2016 to February 2017.

- $\quad$ IMPS - In India, Immediate Payment Services is an inter-bank electronic payments transfer system that operates in real time. An IMP is a mobile phone-based inter-bank electronic fund transfer service. In the three months since demonetization, IMPS have grown by 65 percent in volume and 48.5 percent in value.

- NACH - (National Automated Clearing House) is a web-based system for banks, financial institutions, corporations, and the government to expedite interbank, high-volume, repeated electronic transactions.

- Prepaid payment devices such as M-wallets and paper coupons have grown from 169 million to 280 million in the last three months.

- $\quad$ ATMs - The number of ATMs in the country has increased by one million.

- Mobile banking — since demonetization, mobile banking has grown by 15 million users in just one month.

These digital payments have increased the number of account holders in just six months after demonetization.

Shift in currency demand- As a result of demonetization, there was a cash shortage, which resulted in a decrease in cash usage in retail transactions. And it leads to digitalisation of retail payments. 


\section{The Government's Initiatives to Attain Financial Inclusion in India}

A sizable portion of the population is still unbanked. Around 2 billion people do not utilise formal financial services, according to the World Bank, and more than half of adults in the poorest households are unbanked.The Government of India has implemented a number of initiatives in favour of the impoverished and neglected sections of society in order to gain the benefits of financial services.

Pradhan Mantri Jan DhanYojana (PMJDY) - An ambitious endeavour of the Indian government, the Pradhan Mantri Jan DhanYojana was announced and officially inaugurated on August 28, 2014. PMDJY is a national financial inclusion mission that takes an integrated strategy to ensure that all households in the country are financially included. The scheme's principal goal is to make it simple for every Indian citizen to obtain a savings bank account, allowing India to achieve financial independence. A zero balance account, a RuPay Debit card, a RuPay Credit card, and a simple loan option created with India's financially disadvantaged in mind are among the features of this scheme.

Direct Benefit Transfer (DBT) - This programme ensures that funds from numerous development programmes reach beneficiaries quickly and directly.

RuPay card -This is a new card that allows all Indian banks and financial institutions to participate in electronic payments. It's a multilateral domestic open loop card payment system.

USSD- Based Mobile Banking - This enables mobile banking through the Use of Supplementary Service Data That Isn't Structured (USSD). Money transfers, bill payments, balance enquiries, and merchant payments are just a few of the services available, without the need to download any software, you can use a simple GSM-based mobile phone to access these and other basic banking services.

Bharat Interface for Money (BHIM) - BHIM is a mobile-based payment system that allows for quick, secure, and dependable cashless transactions. It is aimed to promote e-payments directly through banks as part of the 2016 Indian bank note demonetisation and drive towards cashless transactions.

Initiation of no-frills account - Accountholders can use these accounts to make simple deposits and withdrawals, making banking more inexpensive by removing extraneous features that are of no use to the lower class.

Swabhiman - Opening bank accounts in areas with a low population, At the very least, through a cash-servicesbased business correspondent model. Habitats with more than 1600 inhabitants in plain areas and 1000 in mountainous and north-eastern states.

Relaxed and simplified KYC norms - To make it easier for people to open bank accounts, particularly modest ones. Furthermore, banks are permitted to use the Aadhar card as both identification and an address proof.

Simplified Branch Authorisation policy - Domestic SCBs are allowed to open branches freely to solve the issue of bank branches being spread out unevenly. Banks are required to open at least a quarter of their total number of branches in underserved rural areas. 


\section{DISCUSSION AND CONCLUSIONS}

The new faces of banking sector such as PMJDY, DBT, USSD- Based Mobile Banking, RuPay card, BHIM, Swabhiman, Simplified Branch Authorisation policy, Relaxed and simplified KYC norms, Initiation of no-frills account any many more initiatives are directly inflecting the inclusive development in the Indian economy as well as the government must active in crating awareness among all kind of people such as formers uneducated rural communities and other vulnerable groups for better use of this initiatives vulnerable

Financial inclusion is associated to a country's social and economic development, and it helps to alleviate absolute poverty. The use of financial services has surged since demonetisation, and the decision has brought the majority of the financially excluded into the formal banking sector.With the government initiatives like PMJDY, BHIM, Direct Benefit Transfer etc., the disadvantaged people can easily access financial services at affordable cost. Financial inclusion equips people with the knowledge and skills they need to make sound financial decisions.To conclude, the demonetization has a positive impact on the financial inclusion in India but without pre-planned demonetization crate psychological disturbance among the rural and middle call community.

\section{REFERENCES}

1. Kalunda, J. A. (2012). Financial Inclusion and Financial Sector Stability With Reference To Kenya: A Review of Literature. Journal of Applied Finance \& Banking .

2. Moler, D. S. (2017). The Effects of Demonetization on Financial Inclusion in India. InterMedia

3. Agarwal, Parul (2014), "Financial inclusion in India: a Review and Initiatives and Achievements", IOSR Journal of Business and Management, Volume16, Issue6, June.

4. L. V. Kamala Devi, L.V Rajavalli Devi, Impact of Demonetisation on financial inclusion in India. International Conference on "Paradigm Shift in Taxation, Accounting, Finance and Insurance".

5. $\quad$ RBI Bulletin, November 2017.

6. ETNowNEWS.com

7. CRISIL (2013), "Inclusive Financial Inclusion Index", June.

8. Chakrabarthy K. C (2011), "Financial Inclusion: A Road India needs to Travel", RBI Bulletin, November, 2011.

9. Websites, journals and www.com.

10. http:/www.academicjournals.org/ajbm.

11. Beg, S. A. N. A., and NaushadulHaqueMullick. "Increasing financial inclusion through Islamic banking in India." International Journal of Business Management and Research (IJBMR) 6.1 (2016): 27-34.

12. Dixit, Radhika, and Munmun Ghosh. "Financial inclusion for inclusive growth of India-A study of Indian states." International Journal of Business Management \& Research 3.1 (2013): 147-156.

13. Katia, V. I. K. A. S. "Financial inclusion for direct benefit transfer growth and hurdles." International Journal of Economics, Commerce and Research 3.5 (2013): 13-20.

14. Ghosh, MunMun, and Arindam Ghosh. "Financial inclusion Strategies of banks: study of Indian states." International Journal of Applied Financial Management Perspectives 3.2 (2014): 990-996. 
15. Singh, Alka. "Role of technology in financial inclusion." International Journal of Business and General Management 6.5 (2017): 1-6. 